\title{
Liver Cancer Pathologic TNM Finding v6
}

National Cancer Institute

\section{Source}

National Cancer Institute. Liver Cancer Pathologic TNM Finding v6. NCI Thesaurus. Code C61165.

A pathologic finding about one or more characteristics of liver cancer, following the rules of the TNM AJCC v6 classification system. TNM pathologic findings are based on clinical findings supplemented by histopathologic examination of one or more tissue specimens acquired during surgery. 